\title{
DO THE DATA ON MUNICIPAL EXPENDITURES IN THE CZECH REPUBLIC IMPLY INCORRECTNESS IN THEIR MANAGEMENT?
}

\author{
Milan Půček, Michal Plaček, František Ochrana
}

\section{Introduction}

By way of public budgets is in economically developed countries redistributed approximately one half of the produced GDP. According to the EUROSTAT data (EUROSTAT, 2012), total government expenditures in the EU countries (EU-27) accounted in 2012 for $48.9 \%$ of GDP, of which expenditures on the local governments' level accounted for $11.5 \%$ of GDP. In the Czech Republic, these expenditures stood in 2012 at $43.9 \%$ of GDP, while local governments' spending accounted for $9.8 \%$ of GDP. A more detailed comparison of the ratio of total public expenditures to GDP and expenditures of local governments to GDP brings the following table.

Distribution of public expenditures between central and local governments depends on a type of the model of fiscal federalism adopted in individual countries. For most of the reviewed countries, we may register a decrease in public expenditures of local governments. The cause could be attributed to a drop in tax revenues due to the economic crisis. Local governments, unlike central governments, do not aim to stabilise the economy using a fiscal policy. With respect to the significant volume of allocated resources, it is desirable to possess information on how are these incurred expenses economically treated. The present state of theoretical reflection is such that examination of municipal expenditures is usually oriented towards analysing municipal expenditures related to a specific area, such as efficiency in provision of municipal services (Pavel \& Sičáková-Beblavá, 2009), in contracting

\begin{tabular}{l|c|c|c|c|c|c}
\multirow{2}{*}{ Tab. 1: } & \multicolumn{6}{c}{ Comparison of total government expenditures to GDP and expenditures of local } \\
governments to GDP in selected countries of Central Europe
\end{tabular}


public services at a local level (Nemec, Ochrana, \& Šumpíková, 2008), on analysis of municipal finances (Peková, 2011) and their indebtedness. In addition to these examinations, further ways are being sought with the aim to streamline outlays of municipal expenditures with a possibility of introducing public administration controlling (Štandová, Mihaliková, \& Mitat’alová, 2007) or indentifying suitable institutional forms (Beblavý \& Šičáková-Beblavá, 2006) or forms of ownership in the provision of services. At the same time, it appears as necessary to look for ways of how to detect possible incorrectness in the management of municipal expenditures and how to improve the public expenditure control system. Towards one of the possible ways points also this study. Using Benford's test, it aims to examine expenditures of the Czech Republic's municipalities recorded in 2012, analyse uncovered results and formulate conclusions with respect to a more effective operation of the control system of public expenditures. As far as our knowledge based on analysis of expert literature goes, Benford's test has not yet been applied within the realm of control of public expenditures. The presented study attempts to carry out such an analysis (on the example of the Czech Republic's municipal expenditures in 2012). The aim of this study is to explore by way of Benford's test municipal expenditures of the Czech Republic that were undertaken within one reference year and based on results of the empirical research to carry out a discussion on the given issue and to formulate theoretical generalisations and practical recommendations for the domain of a control of public expenditures.

\begin{tabular}{|c|c|c|c|c|}
\hline ab. 2: & \multicolumn{4}{|c|}{$\begin{array}{l}\text { General architecture of the control system of public expenditures } \\
\text { (case of the Czech Republic) }\end{array}$} \\
\hline Criterion & Type of control & Subject of control & Monitored indicator & Monitoring question \\
\hline \multirow[t]{2}{*}{ Content focus } & Content control & $\begin{array}{l}\text { Control of results (audit } \\
\text { of results, performance audit) }\end{array}$ & $\begin{array}{l}\text { Agreement between achieved } \\
\text { results and specified expenditure } \\
\text { targets }\end{array}$ & $\begin{array}{l}\text { How are performance indicators } \\
\text { being met? How are met criteria } \\
\text { of economy, efficiency and } \\
\text { effectiveness? }\end{array}$ \\
\hline & Formal control & $\begin{array}{l}\text { Control of receipts and legal } \\
\text { review of documents }\end{array}$ & $\begin{array}{l}\text { Compliance with the Act on } \\
\text { Accounting and legal compliance } \\
\text { with expenditure documents }\end{array}$ & $\begin{array}{l}\text { Are accounts and expenditure } \\
\text { documents kept correctly from } \\
\text { a formal aspect? }\end{array}$ \\
\hline \multirow{3}{*}{ Time aspect } & Preliminary & $\begin{array}{l}\text { Ex ante control of planned } \\
\text { expenditure activities }\end{array}$ & $\begin{array}{l}\text { Choice of the most appropriate } \\
\text { allocation variant of public } \\
\text { expenditures }\end{array}$ & $\begin{array}{l}\text { Has the chosen variant } \\
\text { been economically the most } \\
\text { appropriate one? }\end{array}$ \\
\hline & Running & $\begin{array}{l}\text { Continuous monitoring of } \\
\text { achieved results and control } \\
\text { of receipts and documents }\end{array}$ & $\begin{array}{l}\text { Continuous monitoring of meeting } \\
\text { the predetermined indicators }\end{array}$ & $\begin{array}{l}\text { Are the predetermined } \\
\text { indicators being met at review } \\
\text { time points? Do expenditure } \\
\text { activities correspond with formal } \\
\text { requirements? }\end{array}$ \\
\hline & $\begin{array}{l}\text { Subsequent and } \\
\text { concluding }\end{array}$ & $\begin{array}{l}\text { Concluding content and formal } \\
\text { review of the undertaken } \\
\text { expenditure activity }\end{array}$ & $\begin{array}{l}\text { Final control of the achieved results } \\
\text { and the degree of compliance with } \\
\text { accounting and legal practices }\end{array}$ & $\begin{array}{l}\text { Do the final results correspond } \\
\text { with the planned objective? Are } \\
\text { all the formal (accounting and } \\
\text { documentation) procedures in } \\
\text { accordance with the principles } \\
\text { of accounting and the legal code? }\end{array}$ \\
\hline \multirow[b]{2}{*}{ Institutional } & Internal control & $\begin{array}{l}\text { Content, formal, preliminary, } \\
\text { running and concluding } \\
\text { control by the institution itself }\end{array}$ & $\begin{array}{l}\text { Indicators of the content and formal } \\
\text { control listed above, monitored by } \\
\text { an internal audit }\end{array}$ & $\begin{array}{l}\text { Do the controlled indicators } \\
\text { correspond with the norm } \\
\text { specified by the Act on Financial } \\
\text { Control and other relevant legal } \\
\text { norms? }\end{array}$ \\
\hline & External control & $\begin{array}{l}\text { Content, formal, running and } \\
\text { concluding control carried } \\
\text { by an external independent } \\
\text { institution - in CZE severely } \\
\text { limited (by the Supreme Audit } \\
\text { Office) }\end{array}$ & $\begin{array}{l}\text { Indicators of the content and formal } \\
\text { control as listed above, monitored } \\
\text { by an external audit }\end{array}$ & $\begin{array}{l}\text { Do the controlled indicators } \\
\text { correspond with the norm } \\
\text { specified by the Act on Financial } \\
\text { Control? }\end{array}$ \\
\hline
\end{tabular}

Source: own based on Act No. 320/2001 Coll., On Financial Control in Public Administration 


\section{Theoretical Foundations of the Research}

The starting point for control of public expenditures is a duly effective control system of public spending. The issue of a control of public expenditures has already been studied within expert literature for several decades. Authors usually devote in detail to a particular aspect of a control of public expenditures, such as e.g. the issue of a financial control, audit of public sector organisations or program evaluation and performance measurement. Within countries of the former Eastern bloc emerges the issue of a control of public expenditures approximately for the past ten years (see e.g. Štangová, Mihaliková, \& Mital'ová, 2007). Based on the analysis of a discussion on the issue of a control of public expenditures within expert literature and the existing control system of public expenditures in the Czech Republic, the system of a control of public expenditures may be characterised from different perspectives, as shown in Table 2. The table provides a synthesis of views on the issue of a control of public expenditures. As a starting point it takes the situation as within conditions of the Czech Republic specified by the Act No. 320/2001 Coll., On Financial Control in Public Administration.

From the content perspective, the control system of public expenditures focuses both on the economic aspect of spending activities (monitoring of the achieved results) as well as on the formal (accounting and documentation) verification of the correctness of carried expenditure activities. From the time aspect, we distinguish between preliminary, running and final inspection. It may be directed both to the area of auditing results of implemented spending activities as well as on a formal verification of the correctness (accounting and documentary) of the way those expenditure activities are recorded. From the institutional point of view, the control may be carried either by the institution itself (internal control) or by an external institution. One problematic aspect, however, represents the fact that the control system of municipal expenditures has under the conditions of the Czech Republic its weaknesses and limitations. Municipal expenditures (as opposed to central government expenditures) can not be checked by the Supreme Audit Office. On the part of the Supreme Audit Office can be checked only those expenditures that local governments derive from the state budget. What is missing is thus one of important independent information channels that would serve a feedback on how were municipal expenditures implemented.

Another problem poses the fact that in the practice of control activity, there is established a relative separation of the content control from the formal control. The consequence is that both types of controls in question do not co-operate; respectively, they are often implemented separately (or independently). Expenditure controls usually either intentionally focus only on checking of economic results related to the undertaken expenditures, or concentrate purely on a verification of the formal (accounting and documentation) correctness of the carried outlays. The fact that both types of control remain unlinked means some valuable information get lost or remain potentially unused while they could lead to an increase in efficiency of the control system of public expenditures, exposure of formal and material errors in resource allocations or possible frauds and machinations in the management of public resources. Therefore, it is desirable to seek ways to contribute to a more effective control of public spending and to utilise acquired information in a comprehensive monitoring of expenditure activities. One of these ways may represent signalling of accounting and record-keeping irregularities in expenditure management activities, acquired through a formal control. This information may subsequently trigger a content control to review the economic rationality (economy, efficiency and effectiveness) of the carried expenditures. One of the tools that are instrumental to acquire signalling information on possible errors in the management of public expenditures is the use of Benford's test.

Benford's Law builds on the idea of the "first digit law", formulated in 1881 by an American astronomer Simon Newcomb in the article entitled "Note on the Frequency of Use of the Different Digits in Natural Numbers" published in The American Journal of Mathematics. In this article he holds that the probability of the first digit in a number being 1 is not $0.111(1: 9=0.1111)$ as might be expected, but rather 0.301 . This proposition was rediscovered by Frank Benford and formulated in detail in the article "The Law of Anomalous Numbers" (Benford, 1938). Benford supported his investigation by 
an analysis of more than 20,000 data samples. Within his analysis, Frank Benford sought to utilise the widest possible data sources from random numbers, street numbers, lake surface areas, population data, or statistics from the American Basketball League (Nigrini, 2011).

Mathematical application of Benford's Law is dealt with by Hill (1995a; 1995b; 1998) and Berger and Hill (2011). As fundamental may be considered the following theorem, based on the Central Limit Theorem: "Provided the chosen distribution is a random one and provided from any such a distribution we pick a random sample, significant numbers from this distribution converge to the logarithmic distribution, alias Benford's distribution", as put by Hill (1998).

The probability of an occurrence of the first digit $\mathrm{D} 1$ based on Benford's distribution is:

$$
\begin{aligned}
& P\left(D_{1}=d_{1}\right)=\log \left(1+\left(\frac{1}{d_{1}}\right)\right) \\
& d_{1} \in\{1 \ldots 9\}
\end{aligned}
$$

The probability of an occurrence of the second digit $\mathrm{D} 2$ based on Benford's distribution is:

$$
\begin{aligned}
& P\left(D_{1}=d_{1}\right)=\log \left(1+\left(\frac{1}{d_{1} d_{2}}\right)\right) \\
& d_{1}=1 \quad d_{2} \in\{1 \ldots 9\}
\end{aligned}
$$

If we extend our analysis to the occurrence of a number on the $n$-th position, we make use of the following general formula:

$$
P_{n}\{d\}=\frac{1}{\ln (B)} \sum_{k=B^{n-1}}^{B^{n}-1} \ln \left(1+\frac{1}{k B+d}\right)
$$

The first application of Benford's Law in the field of accounting was performed by Carslaw (1988) who claimed that when the net income of a company is just below a given psychological level its managers will tend to round this income up. For example, if we have a net income of 798,000 and 19.97 million, managers will try to round these numbers to the amount of 800,000 and 20 million, respectively. This activity is understandable due to the management incentive programs. Carslaw claimed that this behaviour can be detected using Benford's Law, i.e. within the data set there will be a higher occurrence of zeros in the second position and a lower incidence of the number 9 in the second position when compared to Benford's distribution.

The research of Carslaw was followed by Thomas (Nigrini \& Mittermaier, 1997) who examined rounding of tax losses in the USA. His further analysis focused on Earnings per Share (EPS), for which the number nine occurred on the last position less frequently than expected. This resulted in a claim that Earnings per Share are rounded up while losses are rounded down. In 1993, Gupta and Christian (Nigrini \& Mittermaier, 1997) analysed data of taxpayers reported in tax returns. The study focused on taxpayers with an income less than USD 100,000 . Provided a taxpayer in this category reduces his income by a few dollars, he may fall into a lower tax rate bracket. The findings uncovered an income misrepresentation by taxpayers who ranked on the border line for an increase in their marginal tax rate.

A significant shift in the theory of Benford's Law application in the domain of accounting fraud detection is credited to Nigrini (1993; 1996; 2011). Nigrini in his first study (Nigrini, 1993) examined the first and second digit in interests paid and interests credited on a sample of about 200,000 tax returns from 1985 to 1988 . The result was a bias towards lower numbers for interests accrued and higher numbers for interests paid. This research was followed by practical case studies of specific companies, such as the test of first digits, second digits and first two digits of invoices issued by an oil company in order to detect duplicates in documents. Another application was an analysis of rounding in numbers.

Examinations by Nigrini are summarised by Durtshi, Hillison and Pacini in their study "The Effective Use of Benford's Law to Assist in Detecting Fraud in Accounting Data" (Durtschi, Hillison, \& Pacini, 2004) where they also provide a guide for the application of Benford's Law in forensic audit. Conclusions from the mentioned sources can be summarised into the following overview table (Tab. 3).

Results of this generalisation (see Tab. 3) related to conditions and instances of the use of Benford's Law within the domain of a formal control (in this case accounting) will be adopted as a basis for an empirical analysis of aggregate data on municipal public expenditures in the Czech Republic. 


\begin{tabular}{c|c|c|l} 
Tab. 3: Terms and examples of use of Benford's Law in accounting \\
Nr. & $\begin{array}{c}|c| \\
\text { Data for the use of Benford's Law } \\
\text { should satisfy the following conditions }\end{array}$ & Nr. & $\begin{array}{l}\text { Benford's law can be used to detect the } \\
\text { following data manipulations }\end{array}$ \\
\hline 1 & $\begin{array}{l}\text { All data in the data set must be recorded in } \\
\text { the same unit }\end{array}$ & 1 & $\begin{array}{l}\text { Rounding of economic performance by } \\
\text { managers, e.g. rounding of profit from } \\
789,000 \text { to 800,000 }\end{array}$ \\
\hline 2 & $\begin{array}{l}\text { Data must not be limited by their maximum } \\
\text { and minimum value }\end{array}$ & 2 & $\begin{array}{l}\text { Upward rounding of net income and EPS } \\
\text { (earnings per share) }\end{array}$ \\
\hline 3 & $\begin{array}{l}\text { Data can not be numbers used for } \\
\text { identification purposes and they are not } \\
\text { generated randomly }\end{array}$ & 3 & Downward rounding of losses \\
\hline 4 & Data should consist of rather small values & 4 & Duplicity of financial figures, e.g. invoices \\
\hline 5 & It is advisable to have larger data sets & 5 & Wiping data off \\
\hline 6 & $\begin{array}{l}\text { Data should not be influenced by } \\
\text { a psychology, e.g. pricing ending with } 99\end{array}$ & 6 & Rewriting figures \\
\hline
\end{tabular}

Source: own based on Nigrini and Mittermaier (1997); TPA Horwath (2011)

\begin{tabular}{|c|c|c|c|}
\hline \multirow[t]{2}{*}{ Tab. 4: } & \multicolumn{3}{|c|}{$\begin{array}{l}\text { Conclusions from the analysis of studies applying Benford's Law } \\
\text { on the control of macroeconomic data }\end{array}$} \\
\hline & Study \# 1 & Study \# 2 & Study \# 3 \\
\hline $\begin{array}{l}\text { Name of } \\
\text { the study }\end{array}$ & $\begin{array}{l}\text { On the Application } \\
\text { of Benford's Law } \\
\text { to International } \\
\text { Macroeconomic Statistics } \\
\end{array}$ & $\begin{array}{l}\text { Benford's Law and } \\
\text { Macroeconomic Data } \\
\text { Quality }\end{array}$ & $\begin{array}{l}\text { Fact and Fiction in EU } \\
\text { Governmental Economics Data }\end{array}$ \\
\hline $\begin{array}{l}\text { Year of } \\
\text { publication }\end{array}$ & 2007 & 2009 & 2011 \\
\hline Topic & $\begin{array}{l}\text { Tests of data on the } \\
\text { development of GDP } \\
\text { in OECD countries and } \\
\text { Africa. }\end{array}$ & $\begin{array}{l}\text { Macroeconomic data of } 80 \\
\text { countries and comparison } \\
\text { of results with an alternative } \\
\text { method of assessment of } \\
\text { the macroeconomic data } \\
\text { quality - the IMF's Data } \\
\text { Assessment Framework. }\end{array}$ & $\begin{array}{l}\text { National accounts of the } \\
\text { EU MSs on data related to } \\
\text { compliance with the SGP: } \\
\text { (1) Government deficit } \\
\text { and debt, (2) Government } \\
\text { revenue, expenditures and } \\
\text { main aggregates, (3) GDP, } \\
\text { (4) Balance sheet, consolidated } \\
\text { assets and liabilities. }\end{array}$ \\
\hline $\begin{array}{l}\text { Main } \\
\text { conclusions }\end{array}$ & $\begin{array}{l}\text { (1) Most of the data } \\
\text { converged to Benford's } \\
\text { distribution. } \\
\text { (2) Benford's test may } \\
\text { serve as an indicator } \\
\text { of poor quality and } \\
\text { manipulations with data. }\end{array}$ & $\begin{array}{l}\text { (1) Data for some countries } \\
\text { did not converge to Benford's } \\
\text { distribution despite the fact } \\
\text { that their statistical data } \\
\text { were on the basis of the IMF } \\
\text { ranking marked as good } \\
\text { (Japan, Finland). } \\
\text { (2) Non-conformity with } \\
\text { the test may be caused } \\
\text { e.g. by structural changes } \\
\text { in the economy, seasonal } \\
\text { adjustments, etc. }\end{array}$ & $\begin{array}{l}\text { (1) The largest deviations from } \\
\text { Benford's distribution indicated } \\
\text { data for Greece and Lithuania } \\
\text { while the lowest deviation } \\
\text { recorded data for the Czech } \\
\text { Republic (tested for the first } \\
\text { time) and Poland. } \\
\text { (2) Benford's test can be used } \\
\text { as a first instance test that may } \\
\text { indicate data manipulations. }\end{array}$ \\
\hline
\end{tabular}


Within the scope of Benford's Law application on macroeconomic data, there were published three major studies. In the first study "On the application of Benford's Law to International Macroeconomic Statistics" Nye and Moul (2007) focus on tests of data related to the development of GDP in OECD member states and Africa. In the second study ("Benford's Law and Macroeconomic Data Quality"), its authors Gonzales and Pastor (2009) focus on testing of macroeconomic data collected from 80 countries while the results were compared with an alternative method of assessment of the macroeconomic data quality, the IMF's Data Assessment Framework, based on which are compiled rankings of countries according to the quality of statistical data (Data Dissemination Reports on the Observance Standards and Codes). The last published study (Rauch, Göttsche, Brähler, \& Engel, 2011) examined national accounts of the EU member states on data related to the performance of the Stability and Growth Pact. The authors formed a ranking of countries based on the average deviation of $x^{2}$ test results. Comparison of these studies and their conclusions are summarised in Table 4.

Authors of all three studies agree that the application of Benford's test on macroeconomic data may help to identify data with a higher probability of data manipulation. At the same time, however, it is necessary to take into account also the constraints that from this adoption arise. These include primarily erroneous results due to structural changes in the economy, adjustments for seasonality and macroeconomic transformations. Conclusions of these studies are relevant for interpreting results of empirical examinations that use Benford's Law.

In addition to the above-mentioned adoption within the domain of accounting, auditing and analysis of macroeconomic data, application of Benford's Law was also tested in analysing results of the elections in the USA (Decker, Myagkov, \& Ordeshook, 2011), in fiscal (tax) control (Watrin, 2008), insurance (Maher \& Akers, 2002) and also in verifying credibility of regression coefficients in scientific articles, as reported by Diekmann (2007), Diekmann and Jann (2010) and Tödter (2009). In the literature, we were unable to identify any application of Benford's test on a lower than macroeconomic level, e.g. within the domain of municipalities.
This study, therefore, likely stands to be the first examination that audits municipal expenditures using Benford's Law.

\section{Results of the Empirical Research}

The research focused on examination of data from municipalities in the Czech Republic. To be specific about the general characteristics of the object of investigation, let us observe that as of December 31, 2012, there were in total 6,246 municipalities in the Czech Republic with $10,503,477$ inhabitants, while in municipalities over 2,000 inhabitants there lived in total $73.2 \%$ of the overall population. Management of municipalities is in the Czech Republic governed by their annual budget and the budget outlook, as specified by the Act No. 250/2000 Coll., On Budgetary Rules of Regional Budgets. Within the research, we have worked along the lines of the binding classification of municipal budgets - the budgetary structure, specified by the Regulation of the Ministry of Finance of the Czech Republic No. 323/2002 Coll., On Budgetary Structure. Description of public administration reforms in the Czech Republic is provided e.g. in (Špaček \& Neshybová, 2010).

For the purposes of empirical analysis were used aggregate data sourced from the Ministry of Finance of the Czech Republic. The data refer to the year 2012 and represent sums of public expenditures in the structure of the statement of budgetary execution and control of all municipalities in the Czech Republic, divided into categories according to the population (see Tab. 5). For the data analysis there were used statistical methods, hypothesis testing, linear regressions and comparisons. The aim was to examine whether aggregate data on public expenditures of municipalities in the Czech Republic converge to Benford's distribution. For this purpose, municipalities in the Czech Republic were divided into 12 categories according to the size of their population, as shown in Table 5.

Aggregation of data using the respective size of municipalities was chosen for two reasons. The first reason is the fact that with regard to the total number of municipalities in the Czech Republic (6,246 municipalities), within this study it was not practicable to examine all expenditures for all municipalities. The second reason for opting for an aggregation was the fact that size-categories of municipalities allow benchmarking and therefore make it possible to 


\section{Tab. 5: Number of tested data in municipality-size categories}

\begin{tabular}{c|c|r|r|r|r|r} 
Nr. & $\begin{array}{c}\text { Municipal size-ca- } \\
\text { tegory based on } \\
\text { population }\end{array}$ & $\begin{array}{c}\text { Number of } \\
\text { municipali- } \\
\text { ties }\end{array}$ & $\begin{array}{c}\text { \% number } \\
\text { of municipa- } \\
\text { lities }\end{array}$ & $\begin{array}{c}\text { Total popu- } \\
\text { lation of the } \\
\text { category }\end{array}$ & $\begin{array}{c}\text { \% popula- } \\
\text { tion }\end{array}$ & $\begin{array}{c}\text { Average } \\
\text { population }\end{array}$ \\
\hline 1 & $0-100$ & 477 & $7.64 \%$ & 34,406 & $0.33 \%$ & 72 \\
\hline 2 & $101-200$ & 1,001 & $16.03 \%$ & 149,812 & $1.43 \%$ & 150 \\
\hline 3 & $201-500$ & 2,007 & $32.13 \%$ & 656,988 & $6.25 \%$ & 327 \\
\hline 4 & $501-1,000$ & 1,362 & $21.81 \%$ & 960,870 & $9.15 \%$ & 705 \\
\hline 5 & $1,001-2,000$ & 726 & $11.62 \%$ & $1,016,461$ & $9.68 \%$ & 1,400 \\
\hline 6 & $2,001-5,000$ & 400 & $6.40 \%$ & $1,215,137$ & $11.57 \%$ & 3,038 \\
\hline 7 & $5,001-10,000$ & 142 & $2.27 \%$ & 971,336 & $9.25 \%$ & 6,840 \\
\hline 8 & $1,0001-20,000$ & 68 & $1.09 \%$ & 954,676 & $9.09 \%$ & 14,039 \\
\hline 9 & $20,001-50,000$ & 42 & $0.67 \%$ & $1,217,062$ & $11.59 \%$ & 28,978 \\
\hline 10 & $50,001-100,000$ & 16 & $0.26 \%$ & $1,137,171$ & $10.83 \%$ & 71,073 \\
\hline 11 & $100,001-1,000,000$ & 4 & $0.06 \%$ & 947,894 & $9.02 \%$ & 236,974 \\
\hline 12 & $1,000,001+$ & 1 & $0.02 \%$ & $1,241,664$ & $11.82 \%$ & $1,241,664$ \\
\hline & Total & 6,246 & $100.00 \%$ & $10,503,477$ & $100.00 \%$ & 1,682 \\
\hline
\end{tabular}

Source: Data on the number of municipalities from the Czech Statistical Office. Table and calculations by authors.

compare the test results of a specific municipality with results of a particular municipality sizecategory. The aim was to test the hypothesis that aggregate data on municipal expenditures converge to Benford's distribution.

Data for the year 2012, requested from the Ministry of Finance of the Czech Republic, were structured based on sections of the sectoral breakdown, where each section contained all items based on class breakdown that have over the period reported some movement (i.e. at least one municipality included in the respective size-category has accounted for this item). Until 2012, reporting of the public sector in the Czech Republic has been based on the so-called Cash Principle. This approach differs from the practice in Western countries (e.g. United Kingdom, Finland, Switzerland) where are put higher demands on the explanatory power of accounting statements of the public sector, as shown by Sinervo (2014), Lombrano and Zanin (2013) and Bergman (2012). Transition from cash-based accounting of the public sector towards accrual accounting is one of the core tools of public financial management reforms in line with the philosophy of the New Public Management (Hood, 1995).

Within the first part of the empirical analysis, we have verified on aggregate data whether the data on municipal public expenditures converge to Benford's distribution. The test criterion is Mean Absolute Deviance (hereinafter MAD), calculated as follows:

$$
M A D=\frac{\sum_{i=1}^{K}|A P-E P|}{K}
$$

where:

AP - proportion of occurrence of individual numbers in the empirical distribution,

EP - proportion of occurrence of individual numbers in Benford's distribution,

$\mathrm{K}$ - number of digits.

The following Table 6 shows critical MAD values for empirical data, based on which we can decide on the conformity with Benford's distribution - 3 degrees of conformance, the fourth one for nonconformity. These values 
Tab. 6:

Critical MAD values for the first number

\begin{tabular}{l|l}
\hline MAD value & \multicolumn{1}{|c}{ Degree of conformity with Benford's distribution } \\
\hline $0.000-0.006$ & Close conformity \\
\hline $0.006-0.012$ & Acceptable conformity \\
\hline $0.012-0.015$ & Lower conformity \\
\hline 0.015 and more & Nonconformity \\
\hline
\end{tabular}

Source: Nigrini (2011)

Tab. 7: Results of Benford's test applied to aggregate data on municipal public expenditures in the Czech Republic according to size-categories based on population

\begin{tabular}{l|c|c|c|c}
$\begin{array}{c}\text { Size-category based } \\
\text { on population }\end{array}$ & $\begin{array}{c}\text { Number of } \\
\text { tested data }\end{array}$ & MAD value & $\begin{array}{c}\text { Order based } \\
\text { on MAD }\end{array}$ & Assessment verdict \\
\hline $0-100$ & 1,404 & 0.006941550 & 10 & Acceptable conformity \\
\hline $101-200$ & 2,446 & 0.004812095 & 5 & Close conformity \\
\hline $201-500$ & 4,203 & 0.003228490 & 1 & Close conformity \\
\hline $501-1,000$ & 4,679 & 0.005652321 & 6 & Close conformity \\
\hline $1,001-2,000$ & 4,371 & 0.006520248 & 9 & Acceptable conformity \\
\hline $2,001-5,000$ & 4,866 & 0.004004314 & 3 & Close conformity \\
\hline $5,001-10,000$ & 4,374 & 0.003456433 & 2 & Close conformity \\
\hline $10,001-20,000$ & 3,870 & 0.004362737 & 4 & Close conformity \\
\hline $20,001-50,000$ & 3,518 & 0.005951687 & 7 & Close conformity \\
\hline $50,001-100,000$ & 2,950 & 0.007030236 & 11 & Acceptable conformity \\
\hline $100,001-1,000,000$ & 2,434 & 0.012114151 & 12 & Lower conformity \\
\hline $1,000,001$ and more & 2,365 & 0.005994241 & 8 & Close conformity \\
\hline
\end{tabular}

Source: own

were derived from empirical studies by Nigrini (2011).

Results broken down by municipal sizecategories are listed in Table 7.

MAD values are also shown in the following chart. Research results given in Table 7 and Figure 1 indicate that the data on public expenditures of municipalities in the Czech Republic converge to Benford's distribution. Eight size-categories (including the City of Prague) recorded the value of MAD at the level of "close conformity" and three categories ranked as "acceptable conformity". Larger, but still acceptable level of deviation from logarithmic distribution recorded only data for the sizecategory of municipalities with a population from 100,001 to $1,000,000$ inhabitants ("lower conformity"). This group includes four cities.

\section{Application of Benford's Test on the Data of Czech Cities for 2012}

The third objective of the research was to conduct an empirical analysis of municipal expenditures in 2012 and to analyse the results I draw conclusions applicable for the control of public expenditures at the level of municipalities of the Czech Republic. The test hypothesis was that based on the analysis of content and structure of the statement of execution and control of city budgets, Benford's test should (most likely) identify statements of cities with types of data manipulations and errors such as rewriting numbers, duplicities, rounding of numbers, wiping off data.

Given the specific nature of the public sector and the character of reported statements it can be assumed that Benford's test should be 


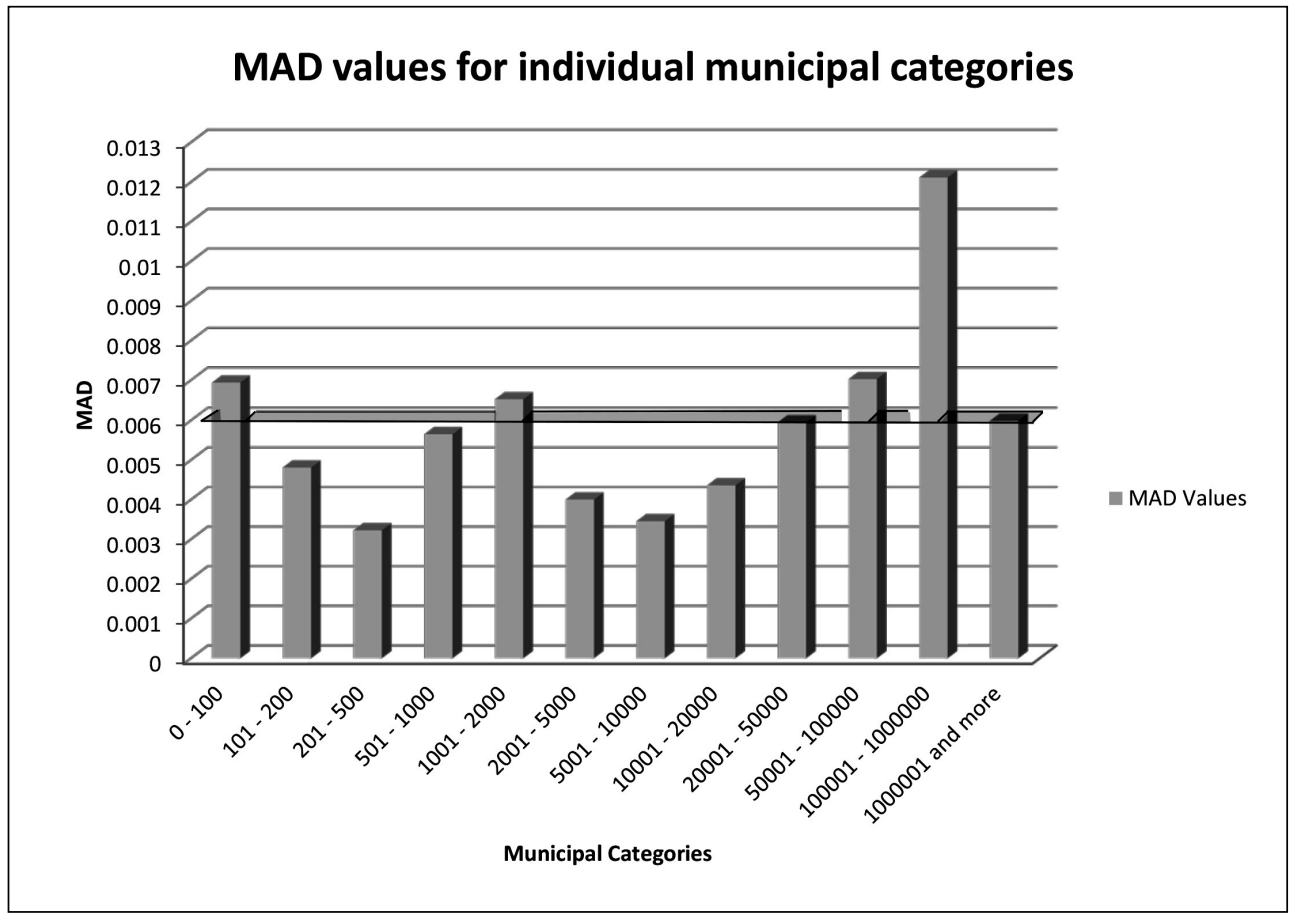

Source: own

able to detect intentional shifts of expenditures between individual budget headings. This activity may be aimed at covering e.g. administrative misconducts of breaching the budgetary discipline. Another motive may be an attempt to move items between the operating and investment parts of the budget in an effort to improve operating results and thus meet the evaluation criteria for securing a bank loan. Another motive may be of a purely political nature, e.g. an attempt to cover up expenses for legal and other consulting services (see findings of the Supreme Audit Office for the period from August to September 2013). The reason for such a data manipulation is to "protect itself" from a negative public reaction towards expenditures related to outsourcing of legal and consulting services by public administration institutions.

For further testing were used data from all municipalities in the Czech Republic with a city status. In total, analysed were public expenditures in the statement of budgetary execution and control of all 602 Czech cities for the year 2012.

On the empirical data was applied the first-level test, i.e. for convergence towards Benford's distribution was tested the first number. This test is generally regarded as the most informative one (Nigrini, 2011). When analysing the convergence of empirical data towards Benford's distribution, we can utilise primarily tests of goodness of fit (Chi-square test, Z-test, Kolmogorov-Smirnoff test). However, these tests are affected by the number of data records (Nigrini, 2011) and at lower numbers of records their values may be distorted. To avoid a possible distortion of results due to a low number of records, we have used as a test criterion the value of Mean Absolute Deviation. The results of Mean Absolute Deviation, however, correlate with the results of tests of goodness of fit.

Based on previous findings, we have applied Benford's test on statements of budgetary 


\section{Tab. 8:}

\begin{tabular}{l|c|c}
\multicolumn{1}{c|}{ Degree of conformity } & Number of cities & Share in \% \\
\hline Close conformity & 6 & 0.997 \\
\hline Acceptable conformity & 126 & 20.930 \\
\hline Lower conformity & 183 & 30.399 \\
\hline Nonconformity & 287 & 47.674 \\
\hline
\end{tabular}

execution and control of individual cities in the Czech Republic. The results are summarised in the following Table 8.

Summary results are presented in Fig. 2 .

According to the results presented in the following table, the application of Benford's test shows a considerable instability. Data in the statements of $47.7 \%$ Czech cities did not converge towards Benford's distribution. This result certainly can not be interpreted in a sense that $47.7 \%$ of statements contained manipulated data. It is only possible to assert that for the given controlled entities (cities), there can be expected existence of a higher probability of errors or data manipulations.
To analyse causes of these results, we sought to identify dependence of Benford's test results on the size of the given city (in terms of its population) and dependence of results on the number of tested data (i.e. the number of items in statements). In order to achieve a greater explanatory power, we have removed from the analysis outliers that were recorded by the cities with largest populations (Prague, Brno and Ostrava).

The tests have shown a significant dependence of MAD on the number of tested data and on the size of cities. Pearson's correlation coefficient reached the value of -0.4587 for the number of tested data and -0.2095 for the city

\section{Summary results of Benford's test}

Close conformity

Accetable conformity

Marginally accetable conformity Nonconformity

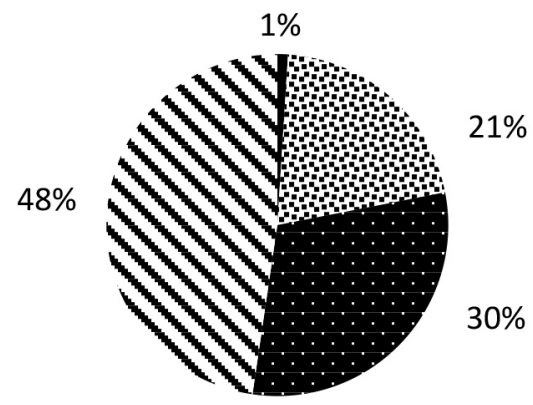


size. Provided we include in our calculations also the cities of Prague, Brno and Ostrava, we still arrive at statistically significant results. Pearson's correlation coefficient reaches the value of -0.147205 for the size of a municipality and -0.390394 for the number of records.

Data were also subjected to a regression analysis, where we tried to explain the behaviour of the dependent variable MAD in response to changes in the above mentioned factors. The research results are shown in Table 9 and Table 10.

Although the factors "population" and "number_of_data" represent, based on the p-value, significant explanatory variables, there still remains unexplained a significant part of the MAD behaviour. To find out the causes of deviations of data for individual cities from Benford's distribution, it would be necessary to carry out the analysis of data and public expenditures directly on the spot. At the same time, it is also necessary to take into account possible significant changes in the structure of expenditures between the years 2011-2012. Such an analysis, however, is outside the scope of ambitions of the presented study, as it would require significant research implementation costs. Nevertheless, based on the examination carried out it is possible to conclude that the results support an argument that Benford's test is appropriate for larger data samples (Nigrini, 2011). At the same time, we face the same problems as earlier studies by Nye and Moul (2007), Gonzales and Pastor (2009), Rauch et al. (2011).

Although Benford's test focuses on the formal aspect of control activity of public expenditures when it e.g. allows detecting intentional shifts between individual budget chapters, such information still provides an impetus for examining the allocative efficiency of public expenditures. That is, the aforementioned shift in expenditures actually represents a change in the purpose of public expenditures and its examining in turn falls under the domain of economic (content) control (see Tab. 2).

Benford's test may indicate also other violations of effectiveness in incurred expenditures, represented by a transfer of items between current and capital expenditures in order to improve the image of the municipal economic management so as to meet the bank criteria to secure a loan. It can also

\begin{tabular}{|c|c|c|c|c|c|}
\hline \multirow[t]{2}{*}{ Tab. 9: } & \multicolumn{5}{|c|}{$\begin{array}{l}\text { Results of regression analysis (omitting extreme values of Prague, Brno } \\
\text { and Ostrava), observations used: } 1-599 \text {; dependent variable: MAD }\end{array}$} \\
\hline & & Coefficient & Std. error & t-stat & p-value \\
\hline \multicolumn{2}{|l|}{ Const } & 0.0231963 & 0.000626024 & 37.0533 & $<0.00001$ \\
\hline \multicolumn{2}{|c|}{ Population } & $5.93548 \mathrm{e}-08$ & $1.65552 \mathrm{e}-08$ & 3.5853 & 0.00036 \\
\hline \multicolumn{2}{|c|}{ Number_of_data } & $-3.24696 e-05$ & $2.73206 \mathrm{e}-06$ & -11.8846 & $<0.00001$ \\
\hline \multicolumn{2}{|c|}{ Adjusted coefficient of determination } & 0.224474 & & & \\
\hline \multicolumn{2}{|c|}{ P-value (F) } & $4.64 e-34$ & & & \\
\hline
\end{tabular}

Source: own

\begin{tabular}{|c|c|c|c|c|}
\hline \multirow[t]{2}{*}{ Tab. 10: } & \multirow[b]{2}{*}{ Coefficient } & \multirow[b]{2}{*}{ Std. error } & \multirow[b]{2}{*}{ t-stat } & \multirow[b]{2}{*}{$p$-value } \\
\hline & & & & \\
\hline Const & 0.0223251 & 0.000571761 & 39.0461 & $<0.00001$ \\
\hline Population & $3.84603 e-08$ & $5.37213 e-09$ & 7.1592 & $<0.00001$ \\
\hline Number_of_data & $-2.81572 \mathrm{e}-05$ & $2.28721 \mathrm{e}-06$ & -12.3107 & $<0.00001$ \\
\hline Adjusted coefficient of determination & 0.216610 & & & \\
\hline P-value (F) & $6.50 \mathrm{e}-33$ & & & \\
\hline
\end{tabular}


lead to shifts between individual items for other reasons, such as, for example, when the municipal management tries to use shifts between individual items of expenditure types to hide from public criticism towards a certain type of spending activities. Also in this case, the original intent (purpose) of the expenditure is being violated. As evident, Benford's test can be one of supporting tools of streamlining the system of control of public expenditures. Its application points at the possibility of systemic interconnection of individual types of municipal expenditure controls into a comprehensive, complex control system of public expenditures, as presented in Table 2 .

The performed analysis shows that the aggregate data for municipalities, assembled into individual categories, converge to Benford's distribution (see Tab. 7). Application of Benford's test on statements of budgetary execution and control of individual Czech cities results in highly unstable results. Based on the correlation analysis, we may conclude that there is a significant correlation between the values of MAD and the number of surveyed data. This means that Benford's test has a greater explanatory power when applied to a larger volume of data, as evident from the case of larger cities. This argument is consistent with other empirical analyses by Nigrini.

The undertaken research indicates that, in addition to errors and data manipulations already specified in the literature, Benford's test may also be adopted for a check against manipulations and data shifting between individual budgetary chapters, which could give a signal to supervisory authorities on a possible (probable) risk of a breach of budgetary discipline.

However, the empirical analysis has shown considerable limitations in the application options of Benford's test, especially due to instability of the results, unavailability of suitable data, the need to transform data before applying the test and a risk of distortion of the results due to incorrect choice of test statistics. Certain restrictions for the use of Benford's test represent also the current level of knowledge and generalisation of its application onto different types of data and accounting statements. In its application, it is therefore necessary to take into consideration other possible factors that may affect the quality of data, such as structural changes in the economy, specifics, and characteristics of individual sectors.

Despite the aforementioned problems, Benford's test may still prove useful to the staff of internal audit and control departments as one of supporting tools that may within data analysis warn against likely occurrences of data manipulation. Subsequently, we may examine whether or not there came to a violation of the principle of effective management of public expenditures. This procedure can also be used as a tool to indicate possible fraud in the normal course of business of organisational units of the public sector (e.g. when examining incoming and outgoing invoices, donations, etc.). Benford's test thus becomes a suitable tool for boosting the efficiency of the public expenditure control system, when within the first stage it allows to identify "problem" subjects, towards which may subsequently focus an in-depth control of public expenditures. Using Benford's test can thus contribute towards finding the ways of how to achieve savings and reduce waste in the public sector (Půček \& Ochrana, 2014), improve the performance of public administration (TPA HORWATH, 2011) and to create an effective system of control of public expenditures.

\section{Conclusions}

The study aimed at adopting the Benford's test to examine municipal expenditures in the Czech Republic for one reference period (year 2012) and based on the empirical analysis to carry out a discussion on the given issue and to formulate relevant theoretical generalisations for the domain of a control of public expenditures. The empirical analysis has confirmed our assumption that Benford's test may be adopted also for examination of municipal expenditures. Nevertheless, there need to be constantly kept in mind the inherent limits of this method. Results of the applied Benford's test show that this test is a suitable tool for the initial detection of data with a higher probability of incorrectness in the handling with public expenditures. We therefore recommend incorporating Benford's test into the system of a control of public expenditure as specified in Table 2. The main contribution of Benford's test for the system for a control of public expenditure is an increase in efficiency and reduction in costs associated with control activities. This way, the controlling body may focus on subjects that prove a higher 
degree of risk of data tempering. A prerequisite, however, is the ability to analyse, evaluate and handle the risk by the controlling body.

The research is a result of the project $P-17$ "Science of a society, politics and media within challenges of the time" by Faculty of Social Sciences, Charles University in Prague.

\section{References}

Beblavý, M., \& Sičáková-Beblavá, E. (2006). Institucionálne dilemy pri zabezpečení verejných služeb. Bratislava: Transparency International.

Benford, F. (1938). The law of anomalous numbers. Proceedings of the American Mathematical Society, 78(4), 551-572.

Berger, A., \& Hill, P. T. (2011). A Basic Theory of Benford's Law. Probability Surveys, 8, 1-126. doi:10.1214/11-PS175.

Bergmann, A. (2012). The Influence of the Nature of Government Accounting and Reporting in Decision - Making: Evidence from Switzerland. Public Money \& Management, 32(1). 15-20. doi:10.1080/09540962.2012.643050.

Carslaw, C. A. P. (1988). Anomalies in Income Numbers: Evidence of Goal Oriented Behaviour. Accounting Review, 63(2), 321-327.

Decker, J., Myagkov, M., \& Ordeshook, C. P. (2011). The Irrelevance of Benford's Law for Detecting Fraud in Elections (Capotech / MIT Voting Technology Project. Working Paper). Retrieved October 9, 2013, from http://www. vote.caltech.edu/drupal/files/rpeavt_paper/ benford_pdf_4b97cc5b5b.pdf.

Diekmann, A., (2007). Not the First Digit! Using Benford's Law to Detect Fraudulent Scientific Data. Journal of Applied Statistics, 34(3), 321-329. doi:10.1080/02664760601004940.

Diekmann, A., \& Jann, B. (2010). Benford's Law and Fraud Detection: Fact and Legends. German Economics Review, 11(3), 397-401. doi:10.1111/j.1468-0475.2010.00510.x.

Durtschi, C., Hillison, W., \& Pacini, C. (2004). The effective use of Benford's law to assist in detecting fraud in accounting data. Journal of Forensic Accounting, 5, 17-34.

EUROSTAT. (2012). Government statistics. Retrieved October 9, 2013, from http://epp.eurostat.ec.europa/portal/ pageúportal/government_finance_statistics/ data/main_table.

Gonzales, J., \& Pastor, G. (2009). Benford's Law and Macroeconomic Data Quality (Working
Paper No. 09/10). International Monetary Fund. Retrieved September 9, 2013, from http://papers.ssrn.com/sol3/papers. cfm?abstract_id=1356437.

Hill, T. P. (1995a). A Statistical Derivation of the Significant-Digit Law. Statistical Science, 10(4), 354-363.

Hill, T. P. (1995b). Base-Invariance Implies Benford's. Proceedings of the American Mathematical Society, 123(3), 887-895.

Hill, T.P. (1998). The First Digit Phenomenon. American Scientist, 86(4), 358-363.

Hood, C. (1995). The "New Public Management" in 1980s: Variations on a Theme. Accounting Organizations and Society, 20(2/3), 93-109. doi:10.1016/0361-3682(93)E0001-W.

Lombrano, A., \& Zanin, L. (2013). IPSAS and Local Government Consolidated Financial Statements - Proposal for a Territorial Consolidation Method. Public Money \& Management, 33(6), 429-436. doi:10.1080/0 9540962.2013.836004.

Maher, M., \& Akers, M. (2002). Using Benford's Law to Detect Fraud in the Insurance Industry. International Business \& Economics Research Journal, 1(7), 1-11. doi:10.19030/ iber.v1i7.3951.

Nemec, J., Ochrana, F., \& Šumpíková, M. (2008). Czech and Slovak Lessons for Public Administration Performance Evaluation, Management and Finance. Ekonomický časopis, 56(4), 353-369.

Nigrini, M. (1993). Can Benford's Law be used in Forensic Accounting? Balance Sheet. 7-8.

Nigrini, M. (1996). A taxpayer compliance application of Benford's law. The Journal of the American Taxation Association, 18(1), 72-91.

Nigrini, M. (2011). Forensic Analytics: Methods and Techniques for Forensic Accounting Investigation. John Wiley \& Sons.

Nigrini, M., \& Mittermaier, L. (1997). The Use of Benford's Law as an Aid in Analytical Procedures. Auditing: A Journal of Practice and Theory, 16(2), 52-67.

Nye, J., \& Moul, C. (2007). The Political Economy of Numbers: On the Application of Benford's Law to International Macroeconomic Statistics. The B. E. Journal of Macroeconomics, 7(1), 1-14.

Pavel, J., \& Sičáková-Beblavá, E. (2009). Testing the Validity of the Brown-Potoski Model in the Czech and Slovak Republics. Prague Economic Papers. Quarterly Journal of Economic Theory and Policy, 18(4), 327-341. 
Peková, J. (2011). Finance územní samosprávy. Praha: Wolters Kluwer.

Rauch, B., Göttsche, M., Brähler, G., \& Engel, S. (2011). Facts and Fiction in EU Governmental Economics Data. German Economics Revue, 12(3), 243-255. doi:10.1111/ j.1468-0475.2011.00542.x.

Půček, M., \& Ochrana, F. (2014). Theory and Practice of the Public Sector Savings: the Case of Czech Regions. Transylvanian Review of Administrative Sciences, 42E, 203-224.

Sinervo, L. M. (2014). Interpreting Financial Balance in Local Government: A Case Study from Finland. Public Money \& Management, 34(2), 123-130. doi:10.1080/09540962.2014.8 87521.

Špaček, D., \& Neshybová, J. (2010). Brief history and current trends of public administration reform in the Czech Republic. In Public Administration in Times of Crisis (pp. 1-18). Bratislava: NISPAcee.

Štangová, N., Mihaliková, E., \& Mital'ová, J. (2007). Controlling vo verejnej správe. E\&M Ekonomie a Management, 10(2), 41-52.

Tödter, K. H. (2009). Benford's Law as an Indicator of Fraud in Economics. German Economic Review, 10(3), 339-351. doi:10.1111/ j.1468-0475.2009.00475.x.
TPA HORWATH. (2011). Nové způsoby odhalování manipulace s účetními daty. Retrieved September 9, 2013, from http://www.tpaahorwath.cz/upload/files/PDF/ Manipulace_s_ucetnimi_daty_JSK_10_08.pdf.

Watrin, C., Struffert, $\bar{R}_{.}$, \& UllImann, R. (2008). Benford's Law: An Instrument for Selecting Tax Audit Targets. Review of Managerial Science, 2(3), 219-237. doi:10.1007/s11846-008-0019-9.

Act No. 320/2001 Coll., On Financial Control in Public Administration.

Ing. Milan Půček, PhD., MBA Charles University in Prague Faculty of Social Sciences

Centre for Social and Economic Strategies milan.pucek@seznam.cz

Ing. Michal Plaček, M.Sc. Charles University in Prague Faculty of Social Sciences

Centre for Social and Economic Strategies

prof. PhDr. František Ochrana, DrSc. Charles University in Prague Faculty of Social Sciences

Centre for Social and Economic Strategies ochrana@fsv.cuni.cz 


\title{
Abstract
}

\section{DO THE DATA ON MUNICIPAL EXPENDITURES INTHE CZECH REPUBLIC IMPLY INCORRECTNESS IN THEIR MANAGEMENT?}

\author{
Milan Půček, Michal Plaček, František Ochrana
}

Limited public resources confront public administration bodies with the question of how to handle them in an economically rational manner. Audit of public expenditures necessitates an ongoing creation and modification of an effective control system. Such a system is made up by subsystems of a formal (accounting and documentation) and economic control, responsible for monitoring the efficiency, effectiveness and economy of managing public expenditures. Significance of such interconnection rests in the fact that the formal control may signal possible improper management of public expenditures. This may become a stimulus for the economic control subsystem to verify the effectiveness, efficiency and economy of outlaid expenditures. For identification purposes related to potential accounting and record-keeping incorrectnesses in the management of public expenditures is proposed adoption of Benford's Law (Benford's test). Benford's test is applied on municipal expenditure data for the year 2012. Data represent sums of public expenditures in the structure of the statement of budgetary execution and control specified by the Regulation of the Ministry of Finance of the Czech Republic No. 323/2002 Coll. For the data analysis there were used statistical methods, hypothesis testing, linear regressions and comparisons. Although the empirical analysis points at a limited use of Benford's test in the conditions of municipal expenditures in the Czech Republic (mainly due to the instability of results and unavailability of suitable data), the analysis showed that Benford's test can be adopted as a supporting tool, suitable for building into the control system of public expenditures. It is one of the ways to increase the effectiveness of a complex control of public expenditures.

Key Words: Control of public expenditures, municipal expenditures, manipulation of public expenditure data, Benford's Law, Benford's test as a signalling tool for auditing public expenditures.

JEL Classification: H72, C12, M42.

DOI: 10.15240/tul/001/2016-4-007 